Joanna Gul

ORCID: 0000-0001-5045-8640

Uniwersytet Wrocławski

\title{
Batuta w ruchu, czyli 209 batut dyrygenckich w portalu www.batuty.instrumenty.edu.pl
}

W 2018 roku udostępniono publicznie portal internetowy „Batuty w zbiorach polskich" www.batuty.instrumenty.edu.pl, powstały na zlecenie Instytutu Muzyki i Tańca w Warszawie, zawierający dokumentację fotograficzną i merytoryczną 209 batut dyrygenckich oraz 12 przeznaczonych dla nich futerałów z XIX i XX wieku, znajdujących się w polskich zbiorach muzealnych i prywatnych ${ }^{1}$. Jest to obecnie największy na świecie zbiór batut prezentowany w wersji cyfrowej, z obszernymi opisami ich form i zdobnictwa, biogramami dyrygentów lub powiązanych osób i instytucji oraz tekstami prezentującymi batutę w szerszym kontekście historycznym i współczesnym ${ }^{2}$.

Batuty pochodzące $\mathrm{z}$ dwóch muzeów warszawskich (Muzeum Narodowego oraz Teatralnego) to niezmiernie ciekawe obiekty związane z wybitnymi muzykami polskimi, takimi jak Ignacy Jan Paderewski, Aleksander Michałowski, Stanisław Moniuszko czy Zdzisław Górzyński, lub spolonizowanymi dyrygentami — obco-

${ }^{1}$ Portal „Batuty w zbiorach polskich” jest częścią portalu www.instrumenty.edu.pl, prezentującego instrumenty muzyczne w polskich muzeach i kolekcjach. Szczegółowe informacje na temat treści i twórców portalu zamieszczono na końcu tekstu.

${ }^{2} \mathrm{~W}$ polskiej literaturze nie brakuje publikacji o dyrygentach i dyrygenturze, w których batuta pojawia się głównie w anegdotach, jednak brak tekstów o batucie jako obiekcie rzemiosła artystycznego, a także o jej funkcji w kulturze. W katalogach nielicznych muzeów, które posiadają pałeczki dyrygenckie lub prezentowały je na wystawie, znajdziemy na ogół lakoniczne opisy dokumentacyjne (na przykład Paderewski [katalog wystawy], Muzeum Narodowe w Warszawie, Warszawa 2018, s. 242; Ignacy Jan Paderewski: artysta, kolekcjoner, mąż stanu [katalog wystawy], Muzeum Okręgowe im. Leona Wyczółkowskiego w Bydgoszczy, Towarzystwo Muzyczne im. I.J. Paderewskiego w Bydgoszczy, Bydgoszcz 2007, s. 56-57). Kilka drukowanych katalogów prywatnej kolekcji batut Moniki i Tadeusza Strugałów zawiera oszczędne opisy dokumentacyjne kolekcji oraz tekst Alicji Knast na temat historii batuty (A. Knast, Dirigentis Instrumentum. Kolekcja batut dyrygenckich Moniki i Tadeusza Strugałów, Stowarzyszenie im. Ludwiga van Beethovena, Kraków 2005), powtórnie opublikowany w portalu www.batuty.instrumenty.edu.pl. 
krajowcami związanymi artystycznie z dziewiętnastowieczną Warszawą, jak Cezar Trombini, Jan Quattrini czy Adolf Gustaw Sonnenfeld. Większość, bo aż 201 pałeczek dyrygenckich prezentowanych w portalu, należy do trzech wybitnych polskich muzyków i zarazem kolekcjonerów. Janusz Marynowski, dyrygent i dyrektor orkiestry Sinfonia Varsovia, gromadzi batuty używane przez najwybitniejszych współczesnych dyrygentów, jak Jerzy Semkow, Jerzy Maksymiuk czy Yehudi Menuhin, oraz kilka obiektów zbudowanych przez wybitnego twórcę batut Richarda Horowitza (ciekawostką jest prywatna umowa między Marynowskim a Menuhinem, wedle której dyrygent oddawał kolekcjonerowi każdą batutę złamaną podczas koncertów w Polsce ${ }^{3}$ ). Krzysztof Słowiński, dyrygent i pianista oraz wnuk Zdzisława Górzyńskiego, udostępnił do dokumentacji cenne batuty z XIX i XX wieku oraz dwa oryginalne, bambusowe futerały wykonane na zamówienie dziadka. Trzeci z kolekcjonerów, Jan Stanisław Witkiewicz, pisarz, krytyk muzyczny i fotograf związany $\mathrm{z}$ baletem i operą, zgromadził prezentowaną $\mathrm{w}$ portalu niezwykle bogatą i interesującą (171 obiektów!) kolekcję batut z XIX i XX wieku pochodzących głównie z Wielkiej Brytanii, Niemiec oraz Stanów Zjednoczonych, a także nielicznych z Rosji (lub zaboru rosyjskiego, w tym Królestwa Polskiego) i innych stron świata. Niektóre z nich należały do znanych dyrygentów, jak Johann Strauss (syn?), Howard Barlow, Frank J. Black, James Moodie, a także polskich chórów z pierwszej połowy XX wieku.

\section{Cechy batut}

Batuta, choć nie wydaje dźwięków jak instrumenty, jest narzędziem ściśle związanym z życiem muzycznym ${ }^{4}$. Pełni przewodnią funkcję $w$ orkiestrze, zastępując wskazywanie palcem czy dłonią, przekazując gesty kierowania i dyscyplinowania, co przynosi skojarzenia z buławą czy berłem (wygląd podobny do buławy zachowała do dziś masywna i długa batuta używana przez kapelmistrzów orkiestr marszowych, zwana buławą marszową lub batutą tamburmajora). Nie jest konieczna, aby prowadzić zespół muzyków — nie każdy dyrygent jej używa, zwłaszcza chórmistrzowie od trzymania batuty wolą bogate w znaczenia gesty obu dłoni. Jednak dyrygenci prowadzący orkiestry symfoniczne najczęściej z nich korzystają. Współczesne batuty to cienkie ,patyczki” z drewna lub tworzywa sztucznego z szerszym uchwytem. W takim kształcie są spotykane do-

${ }^{3}$ Informacja Agaty Mierzejewskiej od J. Marynowskiego. Zob. ułamane batuty Y. Menuhina: http:// www.batuty.instrumenty.edu.pl/pl/kolekcje/collections/collection/7 (dostęp: 28 października 2018).

${ }^{4}$ Ciekawym wyjątkiem są rzadko spotykane batuty z kamertonem języczkowym, przytwierdzonym do uchwytu (ukrytym pod nakładką), na którym można zagrać trójdźwięk durowy lub molowy w każdej tonacji, co jest przydatne zwłaszcza w pracy z chórem. Zob. http://www.batuty.instrumenty.edu.pl/pl/baton/show/instrument/417 (dostęp: 28 października 2018). 
piero w początkach XX wieku, natomiast wcześniej były konstruowane w znacznie większych i cięższych formach. Najczęściej spotykana forma batuty w XIX i pierwszej połowie XX wieku to prosty, jednolity, dość gruby trzon z drewna, często hebanu, długości około 25-50 cm (zdarzają się nawet dłuższe!) o kształcie cylindrycznym lub stożkowym, zdobiony metalowymi okuciami lub kościanymi końcówkami — w kosztowniejszych wersjach są to metale szlachetne i kość słoniowa, gustownie ukształtowane, z przeróżnymi grawerowanymi lub rzeźbionymi wzorami. W miejscu przeznaczonym do uchwycenia batuta jest często ozdobnie przewężona. Inskrypcje umieszczano na metalowych tabliczkach lub wstęgach przytwierdzanych do trzonka bądź rzeźbiono je na kościanych uchwytach.

\section{Batuta w ruchu}

Podczas próby lub koncertu batuta jest utrzymywana przez dyrygenta w ciągłym ruchu. Stukanie o pulpit jest sygnałem do wyciszenia zespołu i oczekiwania na znieruchomiały gest, poprzedzający rozpoczęcie utworu. Dalej poprzez różnorodne ruchy batuty dyrygent wyznacza taktowanie, nadaje tempo, dynamikę, pokazuje wejścia poszczególnych instrumentów i grup, domaga się przeróżnych działań orkiestry, a każdy gest jest wykonany z wyprzedzeniem, które umożliwia orkiestrze podążanie za interpretacją dyrygenta. Batuta ujęta w dłoń stanowi przedłużenie ciała dyrygenta i przekazuje jego indywidualność i temperament. Jedni dyrygenci poruszają nią oszczędnie, nie unosząc ręki zbyt wysoko, inni „tańczą” energicznie, szeroko wymachując rękami, niemalże podskakując, jeszcze inni „przecinają i kłują” nią powietrze niczym szpadą. Zdarza się nawet, że dyrygent zrani się, wymachując batutą, lub ją złamie ${ }^{5}$. Przy intensywnych ruchach pałeczka niekiedy wypada dyrygentowi z dłoni i... leci w stronę orkiestry lub publiczności 6 . Może upaść daleko, może też złamać się po upadku, dlatego niektórzy dyrygenci trzymają w zanadrzu drugą batutę (podobnie perkusistom zdarza się wypadnięcie pałek z dłoni, dlatego trzymają blisko siebie zapasowe komplety).

${ }^{5}$ Zranienie podczas dyrygowania koncertem opisał na przykład Krzysztof Dziewięcki (A. Misiewicz, Krzysztof Dziewięcki: Zespót Pieśni i Tańca nie porysowat w Watykanie posadzki, Wyborcza.pl, Magazyn Katowice z dnia 11 września 2015, http://katowice.wyborcza.pl/katowice/1,35055 ,18752918,krzysztof-dziewiecki-zespol-piesni-i-tanca-nie-porysowal-w.html (dostęp: 28 października 2018)). Znana jest też pechowa historia siedemnastowiecznego kompozytora Jeana-Baptisty Lully’ego, który miał umrzeć z powodu zakażenia po zranieniu się w stopę batutą w formie długiej, trzymanej pionowo laski, prawdopodobnie podobnej do współcześnie używanych batut w orkiestrach wojskowych (zob. A. Knast, Dirigentis Instrumentum, http://www.batuty.instrumenty.edu.pl/ pl/historia/dirigentis-instrumentum (dostęp: 28 października 2018)).

${ }^{6}$ Taką kłopotliwą sytuację uczestnika konkursu dyrygenckiego opisała Dorota Szwarcman (blog Co w duszy gra, felieton Fruwa batuta z dnia 21 listopada 2012, https://szwarcman.blog. polityka.pl/2012/11/21/fruwa-batuta/ (dostęp: 28 października 2018)). 
Niektórzy dyrygują wykałaczką, jak Walerij Giergijew. Jeszcze inny rodzaj ruchu wykonuje batutą kapelmistrz orkiestry marszowej, który porusza nią w pionie energicznie i tak wysoko, aby główka była widoczna ponad jego głową.

Dawniej batuty były wyposażone w jasny czubek z kości, błyszczącego w świetle metalu (mosiądzu, srebra, złota) lub jasnego tworzywa sztucznego, dzięki któremu gesty dyrygenta były widoczne na tle jego czarnego fraka i ciemnej sali. Współczesne batuty w formie znacznie lżejszych i cieńszych ,patyczków” z drewna lub tworzywa sztucznego nie mają osobnego czubka, ale jasny, biały kolor trzonka stosowany jest do dziś. Dyrygenci często posiadają kilka własnych batut, niekiedy tworzonych specjalnie dla nich, na zamówienie, które obejmuje dostosowanie właściwości batuty do budowy fizycznej muzyka ${ }^{7}$. Ciało dyrygenta pracuje, jest obciążone długotrwałym, intensywnym ruchem rąk, a także męczącym uchwytem palców. $Z$ tego powodu współczesne batuty, w porównaniu do dawniej stosowanych, wyróżniają się kształtem i lekkością, są cienkie, wykonane z drewna lub tworzywa sztucznego, wyposażone w wygodne, różnie ukształtowane uchwyty z korka lub drewna, pochłaniające pot. Niewątpliwie współczesna, bardzo lekka forma batuty umożliwia znacznie bogatszą gestykulację niż dawna, bardziej masywna i inaczej trzymana.

Dyrygenci podróżują z własnymi batutami. Współcześnie używane są lekkie futerały $z$ tworzywa sztucznego. Dawniej tworzono specjalne, wieloczęściowe formy batut, składane $\mathrm{z}$ dwóch, a nawet trzech skręcanych z sobą części, niekiedy ze specjalnym mechanizmem sprężynowym, zapobiegającym rozłączeniu i zgubieniu elementów i ułatwiającym ich złożenie. Pałeczki rozłożone na części przechowywano w specjalnym futerale wyłożonym miękką tkaniną. Innym sposobem na złożenie długiej batuty było skonstruowanie jej w formie teleskopowej, w której cieńsze części wysuwane są z szerszych, podobnie jak w niektórych wskaźnikach i antenach samochodowych.

$\mathrm{Na}$ wielu zachowanych obiektach prezentowanych $\mathrm{w}$ portalu widać ślady zużycia, wynikające $\mathrm{z}$ ich ruchu — powstałe od trzymania w dłoni i stukania o pulpit zarysowania i złuszczenia lakieru lub wgniecenia politury, przetarcia, ubytki, pęknięcia, ślady po brakujących inkrustacjach czy nawet ułamanie całego trzonu. Używane batuty starzeją się równocześnie z liczbą poprowadzonych prób i koncertów.

\section{Funkcje batuty}

Mobilność można rozpatrywać także w kontekście zróżnicowanych i zmiennych funkcji batut. Służyły bowiem nie tylko do dyrygowania, ale także jako podarunek. Ozdobne, niekiedy bardzo bogato zdobione batuty bywały prezentem muzycznym

7 Jednym z wybitnych twórców batut na zamówienie był Richard Horowitz, amerykański perkusista orkiestry Metropolitan Opera. Zob. www.batuty.instrumenty.edu.pl oraz http://www.wrti. org/post/accidental-baton-maker (dostęp: 28 października 2018). 
dla dyrygentów lub znanych muzyków innej specjalności. Zachowane inskrypcje na pałeczkach wskazują, że bywały podarunkiem od chóru dla własnego dyrygenta z okazji jubileuszu, grania na ważnej uroczystości, niekiedy nawet wystąpienia przed koronowanymi głowami lub też wręczone w nagrodę za wygranie konkursu dyrygenckiego. Batuty-prezenty bywały zdobione zarówno skromnie, jak i niezwykle bogato, można na nich znaleźć misterne rzeźbienia w kości słoniowej, inkrustacje z masy perłowej, srebrne i złote okucia z tłoczonymi wzorami, metalowe wieńce laurowe owijające hebanowy trzonek i wstęgi z grawerowaną dedykacją, zwieńczenia w kształcie liry (bardzo popularny symbol muzyczny) i tym podobne. Obiekty o takim wyglądzie pełniły funkcję swego rodzaju „biżuterii muzycznej”, były wyrazem najwyższego uznania dla talentu muzyka, ale można się domyślać, że raczej nie służyły do dyrygowania. Ozdobna batuta była też używana jako symbol władzy - wszak dyrygent sprawuje funkcję kierowniczą nad powierzonym sobie zespołem, a nieprzypadkowo niektóre batuty przypominają rodzaj berła ${ }^{8}$. $Z$ tej interpretacji zapewne wynika, że niekiedy batutę od zespołu muzycznego otrzymywał nie muzyk, ale burmistrz miasta ${ }^{9}$. W podobny sposób można rozpatrywać prezenty w postaci niezwykle ozdobnych batut dla Ignacego Jana Paderewskiego, który dyrygentem przecież nie był, ale skutecznie działał w sferze politycznej, na długo przed tym, zanim formalnie został politykiem ${ }^{10}$.

Dzięki zachowanym dedykacjom, umieszczonym na uchwytach batut lub przytwierdzonych do nich tabliczkach czy wstęgach, możemy wiele się dowiedzieć — czyje ręce nimi dyrygowały, jaki rodzaj muzyki wykonano i zespół za ich pomocą prowadzono, czy była to orkiestra dziecięca, wojskowa, górnicza czy też chór śpiewający w prestiżowej sali podczas jubileuszu słynnego dyrygenta. $\mathrm{Na}$ przykładzie zgromadzonych obiektów w portalu www.batuty.instrumenty.edu.pl widać, w jak zróżnicowanych środowiskach batuty były użytkowane - potocznie kojarzymy batutę z salą koncertową i muzyką poważną, jednak zachowane inskrypcje pokazują nam także inne realia uprawiania muzyki w XIX i XX wieku. Obok inskrypcji wskazujących na jubileusze orkiestr symfonicznych, wiele dedykacji dotyczy dyrygentów zespołów muzycznych, szczególnie chórów i orkiestr dętych przy brytyjskich kościołach protestanckich oraz charytatywnej organizacji Band of Hope, działającej na rzecz abstynencji wśród dzieci i młodzieży w Wielkiej Brytanii. Angażowanie w aktywność muzyczną było jednym ze sposobów odciągania od używek i kształtowania charakteru, dlatego można tu spojrzeć na batutę jako przedmiot dyscyplinujący, w pewnym sensie kierujący chórzystów

${ }^{8}$ Zob. na przykład batuta z dedykacją dla dyrygenta Carla Hormanna: http://www.batuty.instrumenty.edu.pl/pl/baton/show/instrument/388 (dostęp: 28 października 2018).

${ }^{9} \mathrm{Na}$ podstawie zachowanej batuty burmistrza Dariusa A. Browna, http://www.batuty.instrumenty.edu.pl/pl/baton/show/instrument/363/manufacturer/29 (dostęp: 28 października 2018).

${ }_{10}$ Zob. obiekty podarowane Paderewskiemu zachowane w zbiorach Muzeum Narodowego w Warszawie: http://www.batuty.instrumenty.edu.pl/pl/kolekcje/collections/collection/6 (dostęp: 28 października 2018). 
i muzyków na właściwą drogę życia. Niektóre batuty należały do kapelmistrzów orkiestr dętych, działających przy zakładach przemysłowych, takich jak na przykład kopalnie. Ciekawą pamiątką związaną z kulturą polską na emigracji jest batuta $z$ inskrypcją „PREZENT / DLA / DYRYGENTA PANA / ARLTA OD / K.S.P HÓR [sic!] / NOWOWIEJSKI / OIGNIES 1929;". Wspomniany chór im. Feliksa Nowowiejskiego działał przy parafii katolickiej w północnej Francji w miejscowości Oignies od 1924 roku, składał się głównie z polskich górników, przybyłych $\operatorname{tam} z$ Westfalii po pierwszej wojnie światowej. Zachowana batuta jest przejawem aktywności muzycznej oraz mobilności kultury ${ }^{11}$.

Batuty to obiekty niezwykle ciekawe z powodu swojej historii, funkcji czy przemian $\mathrm{w}$ formie. W niniejszym tekście zaznaczono jedynie niektóre konteksty, związane $\mathrm{z}$ historią wybranych obiektów, zachowanych w polskich muzeach i kolekcjach.

\section{O portalu}

Portal „Batuty w zbiorach polskich” www.batuty.instrumenty.edu.pl został zrealizowany na zlecenie Instytutu Muzyki i Tańca w roku X Międzynarodowego Konkursu Dyrygentów im. Grzegorza Fitelberga w Katowicach (2017). Swoje zbiory udostępniły: Muzeum Teatralne Teatr Wielki — Opera Narodowa w Warszawie ( 6 batut dyrygentów, głównie związanych z Teatrem Wielkim w XIX wie$\mathrm{ku}$ ), Muzeum Narodowe w Warszawie (2 batuty Ignacego Jana Paderewskiego) oraz kolekcjonerzy prywatni: Jan Stanisław Witkiewicz (171 batut, część kolekcji od 2017 roku nadal prezentowana w Muzeum Miejskim Wrocławia), Krzysztof Słowiński (15 batut) oraz Janusz Marynowski (15 batut).

Treści w portalu opracował zespół w składzie: kurator Agata Mierzejewska; fotografie: Waldemar Kielichowski; opisy batut ze zbiorów prywatnych oraz biogramy dyrygentów, osób i instytucji związanych z batutami: Joanna Gul; konsultacja batut z kolekcji J.S. Witkiewicza: Magdalena Szmida-Półbratek (Muzeum Miejskie Wrocławia); opisy batut muzealnych: Katarzyna Wodarska-Ogidel (Muzeum Teatralne, Teatr Wielki - Opera Narodowa) oraz Ryszard Bobrow (Muzeum Narodowe w Warszawie). Ponadto w portalu zamieszczone są anegdoty „Z pamiętnika dyrygenta" zebrane przez Agatę Mierzejewską, teksty: Alicji Knast Dirigentis Instrumentum na temat historii batuty oraz Miłosza Kuli Konkursy dyrygenckie $w$ Polsce $i$ na świecie, a także fotografie sławnych dyrygentów i dyrygujących muzyków, jak na przykład Yehudi Menuhin czy Krzysztof Penderecki, wykonane przez Janusza Marynowskiego.

${ }^{11}$ Zob. http://www.batuty.instrumenty.edu.pl/pl/indeks-osob\#manufacturer_71 oraz http://www. batuty.instrumenty.edu.pl/pl/baton/show/instrument/314/manufacturer/71 (dostęp: 28 października 2018). 